(c) Elsevier Scientific Publishing Company, Amsterdam -- Printed in The Netherlands

\title{
LABORATORY STUDIES ON FOOD INTAKE, GROWTH AND CONVER- SION EFFICIENCY OF PALAEMON LAMARREI IN RELATION TO BODY SIZE
}

\author{
SHAKUNTALA KATRE and S. RAVICHANDRA REDDY \\ Department of Zoology, Bangalore University, Bangalore 560001 (India)
}

(Received 7 December 1976; revised 1 April 1977)

\section{ABSTRACT}

Katre, S. and Reddy, S.R., 1977. Laboratory studies on food intake, growth and conversion efficiency of Palaemon lamarrei in relation to body size. Aquaculture, 11: 247--261.

The effects of body size on the food intake, growth and conversion efficiency of the freshwater prawn Palaemon lamarrei have been studied. In captivity, fed on a restricted diet of the muscles of the fish Gambusia affinis, moulting in these prawns occurred once in $18 \pm 5$ days at a temperature of $26 \pm 1^{\circ} \mathrm{C}$. The importance of these cast moults, contributing a sizable amount of organic matter to the detritus deposit of freshwater habitats has been indicated. In a log-log system, both food intake and growth per day, represented as a percentage of body weight, showed an inverse relationship to the body size. Animals in the size range of $600-800 \mathrm{mg}$ exhibited the highest conversion efficiency. The present study indicates that these prawns can be successfully reared and grown under laboratory conditions.

\section{INTRODUCTION}

Growth rates of larger crustaceans like decapods are mostly studied on the basis of measurements of increase in length or diameter of the organism. Except for the work of Delmando and Rabanol (1956), on Penaeus monodon, other studies on growth rates of Indian species of marine and freshwater prawns, described in the Prawn Fisheries Bulletin (1969) of India, are based on the length frequency distributions of the animals in their respective habitats. Cole and Waugh (1959) considered that the measurements of growth, based on increase in length or diameter of the body, cannot be taken as real indices of growth. Subsequently, Sitaramiah (1966) quantified the growth rate of Palaemon lamarrei under laboratory conditions in terms of weight. Since Marshall and Orr (1960) remarked that the food of crustaceans is only imperfectly known qualitatively and hardly known at all quantitatively, a large number of quantitative studies on food intake, growth and conversion effi- 
ciency of several crustaceans have been carried out: Calanus (Paffenhöffer, 1971), Diaptomus (Comita, 1964; Richman, 1969), Artemia (Sushtchenya, 1962; Reeve, 1963; Mason, 1963; Khmeleva, 1967), Daphnia (Kryutchkova and Sládeček, 1969), Crangon (Regnault et al., 1974) and the review by New (1976). However, in Indian species of freshwater decapod crustaceans studies of this sort are wanting. In the present investigations, food intake, growth and conversion efficiency of the freshwater prawn Palaemon lamarrei were studied quantitatively with particular reference to the effect of body size on the parameters.

\section{MATERIAL AND METHODS}

\section{Experimental animals}

Palaemon lamarrei (H.M. Edwards) grows to a maximum length of $80 \mathrm{~mm}$ and has a wide distribution in the fresh water habitats of India (De Man, 1908; Kemp, 1915; Panikkar and Aiyer, 1939; Patwardhan, 1937; Chopra and Tiwari, 1947). For the present study, prawns of different body sizes were collected from the Bellandur tank (near Bangalore, South India). Test individuals were starved for a period of 3 days prior to the start of the experiment. Two series of experiments were set up. In one series, 33 individuals of different initial wet body weights, ranging from $60 \mathrm{mg}$ to $5.30 \mathrm{~g}$ were selected and reared individually in battery jars (surface area: $78.6 \mathrm{~cm}^{2}$ ) containing $500 \mathrm{ml}$ of filtered fresh water at an ambient temperature of $26 \pm$ $1^{\circ} \mathrm{C}$. In the second series, the prawns were reared in four groups of ten each, each group consisting of individuals of approximately the same body weight. These were reared in larger aquaria (surface area: $471.6 \mathrm{~cm}^{2}$ ) with conditions as in Series 1 and proportional volumes of water ( $500 \mathrm{ml} / \mathrm{prawn})$. The water in the experimental aquaria was aerated every day for $6 \mathrm{~h}$ and the water was changed once in a fortnight.

\section{Food and feeding procedure}

Chopped pieces of muscles of the fish Gambusia affinis were offered as food to the test individuals in both series. A surplus amount of food was offered every day in the early hours of the morning. The prawns were allowed to feed for a duration of 4 hours, at the end of which the remaining uneaten food was removed. The amount of food eaten was determined by subtracting the amount of uneaten food from the amount of food offered. The uneaten muscle pieces were blotted between two sheets of filter paper till dry and then weighed. Thus errors in weight, which may have been caused by the absorption of water by food while in the aquaria, was minimised. Prawn growth, in short term experiments of 4 weeks, is known to be affected by the form of diet (Forster, 1972). In the present 
experiments, feeding was continued for a period of 100 days, at the end of which the individuals were sacrificed and the final weight changes recorded. Average daily food intake $(\mathrm{mg})$, food $(\mathrm{mg}) \cdot[\text { body weight }(100 \mathrm{mg})]^{-1}$. day $^{-1}$, average daily growth $(\mathrm{mg})$, growth $(\mathrm{mg}) \cdot[\text { body weight }(100 \mathrm{mg})]^{-1}$. day ${ }^{-1}$ and conversion efficiency, expressed as $K_{1}=$ daily growth $(\mathrm{mg}) \times$ $100 /$ daily food intake (mg), have been calculated for determining the correlations with the body size of the animal.

\section{Collection of moults}

During the 100-day experimental period, the moulting frequency of each prawn in Series 1 was recorded. The moults produced by the prawns in the second series were recorded and weighed as and when cast. The weight of each cast moult was determined separately after blotting the adhering water. At the end of the 100-day experimental period, the wet weights of all the moults produced by each animal were added to the total increase in wet weight of the individual prawn to calculate total growth. The individual moults were dried overnight in a hot air oven at $95^{\circ} \mathrm{C}$ and weighed. The dry weight of each exuvium was then expressed as a percentage of the final dry weight of the animal.

\section{RESULTS AND DISCUSSION}

\section{Survival rate}

Out of the 33 prawns of Series $1,60.6 \%$ of the individuals survived till the end of the experiment. In the second series, however, there was heavy mortality, mostly due to the cannibalistic behaviour of the individuals comprising each group. The survival rate of prawns at the end of the experiment in Series 2 ranged from 25 to $40 \%$ of the initial number.

\section{Moulting frequency}

Except for the prawns numbers 1 and 25 all specimens in Series 1 moulted three to nine times during the 100-day experimental period. Needham (1946) observed that ecdysis in crustaceans occurred only in the early hours of the morning. During the present studies also, Palaemon lamarrei was always observed to moult at night. Table I presents the moulting frequency of prawns which survived for more than half of the experimental period. These results indicate that, at a temperature of $26 \pm 1^{\circ} \mathrm{C}$ with $4 \mathrm{~h}$ of feeding per day, the moulting of $P$. lamarrei occurred once in 18 days with a standard deviation of 5 days (range: $11-25$ days). Each cast moult averaged $14 \%( \pm 6 \%$ ) of the animal's dry weight. There was no apparent correlation of moulting frequency with the size of the prawn. A similar observation was made in Euphausia pacifica by Lasker (1964). He reported that $\bar{E}$. pacifica moulted once in $5 \pm$ 


\section{TABLE I}

Moulting frequency of Palaemon lamarreii reared individually (Series 1 averages are given \pm SD)

\begin{tabular}{|c|c|c|c|c|c|c|}
\hline $\begin{array}{l}\text { Prawn } \\
\text { number }\end{array}$ & $\begin{array}{l}\text { Final animal } \\
\text { dry weight } \\
(\mathrm{mg})\end{array}$ & $\begin{array}{l}\text { Number of } \\
\text { moults } \\
\text { produced }\end{array}$ & $\begin{array}{l}\text { Average dry } \\
\text { weight per } \\
\text { moult (mg) }\end{array}$ & $\begin{array}{l}\text { Time alive } \\
\text { in labora- } \\
\text { tory (days) }\end{array}$ & $\begin{array}{l}\text { Average } \\
\text { moulting } \\
\text { frequency } \\
\text { (days) }\end{array}$ & $\begin{array}{l}\text { Moults as a } \\
\text { percent of ani- } \\
\text { mal dry weight }\end{array}$ \\
\hline 2 & 24.50 & 8 & 5.52 & 100 & 12.50 & 22.50 \\
\hline 3 & 22.50 & 7 & 2.98 & 100 & 14.28 & 13.30 \\
\hline 4 & 21.00 & 6 & 2.20 & 100 & 16.66 & 10.50 \\
\hline 5 & 14.30 & 3 & 4.20 & 91 & 30.33 & 29.40 \\
\hline 7 & 34.30 & 8 & 2.85 & 100 & 12.50 & 8.60 \\
\hline 8 & 58.20 & 9 & 6.13 & 100 & 11.11 & 10.50 \\
\hline 9 & 71.70 & 6 & 10.08 & 100 & 16.66 & 14.10 \\
\hline 10 & 115.20 & 5 & 9.16 & 100 & 20.00 & 7.90 \\
\hline 11 & 34.50 & 7 & 6.78 & 100 & 14.28 & 19.70 \\
\hline 13 & 70.10 & 5 & 10.34 & 100 & 20.00 & 14.30 \\
\hline 14 & 32.30 & 4 & 8.30 & 80 & 20.00 & 25.00 \\
\hline 15 & 170.00 & 6 & 11.46 & 100 & 16.66 & 7.10 \\
\hline 16 & 110.20 & 7 & 9.52 & 100 & 14.28 & 8.60 \\
\hline 17 & 80.40 & 6 & 12.50 & 86 & 14.33 & 16.30 \\
\hline 18 & 67.80 & 6 & 6.08 & 100 & 16.66 & 9.00 \\
\hline 19 & 170.00 & 7 & 16.51 & 100 & 14.28 & 9.70 \\
\hline 24 & 223.40 & 4 & 37.15 & 100 & 25.00 & 16.60 \\
\hline 26 & 331.80 & 4 & 41.85 & 100 & 25.00 & 12.40 \\
\hline 28 & 352.40 & 6 & 38.25 & 100 & 16.66 & 10.80 \\
\hline 29 & 380.30 & 4 & 40.17 & 100 & 25.00 & 10.50 \\
\hline 30 & 338.50 & 4 & 50.20 & 78 & 19.50 & 20.90 \\
\hline 31 & 829.70 & 6 & 115.21 & 100 & 16.66 & 13.90 \\
\hline 32 & 552.90 & 3 & 134.50 & 57 & 19.00 & 24.20 \\
\hline \multirow[t]{2}{*}{33} & 2514.00 & 4 & 146.38 & 100 & 25.00 & 9.30 \\
\hline & & & & Average & $\begin{array}{r}18.20 \pm \\
4.89\end{array}$ & $\begin{array}{r}14.40 \pm \\
6.32\end{array}$ \\
\hline
\end{tabular}

1 days and that each cast moult averaged $10 \%$ of the animal's dry weight. Six other species of Euphausia are also reported to produce moults equivalent to nearly $10 \%$ of the animal's dry weight (Jerde and Lasker, 1966). In a related freshwater prawn, Macrobrachium rosenbergii, Raman (1967) found that moulting took place at irregular intervals; roughly one moult for every 10 $-\mathrm{mm}$ increase in size. In the same species Rao (1967) reported that immature males moulted six times per year while females moulted only five times.

\section{Feeding behaviour}

Marshall and Orr (1960) stated that a prawn can touch food with its antennae and yet be unable to find it. In contrast to this, Ling (1962) working 
on the giant freshwater prawn Macrobrachium rosenbergii, reported that the prawn located the food material by the sense of touch. In the present series of experiments, as soon as the food material was dropped into the aquarium the prawn grabbed and started "nibbling" at the food. Within a week, the individuals were sufficiently trained to even snatch the food as it was being dropped. As the test prawns were fed daily at a regular time of the day, prawns would anticipate the onset of feeding and come towards the surface of the water to snatch the food. Perhaps sight and chemoreception have important roles to play in the feeding behaviour of $P$. lamarrei.

\section{Food intake}

All the prawns studied in the present experiment (Series 1), showed lower consumption of food on the day of moulting. Thus moulting seems to act as a depressant to feeding. Similar observations were also made in Euphausia pacifica (Lasker, 1966). While reviewing the studies on feeding in aquatic invertebrates, Monokov (1972) reported that daily food consumption may change depending on the size of the animal. The daily food intake of Palaemon lamarreii also depended on the size of the animal. Per day, a larger prawn consumed more food than a smaller prawn; for example, a prawn weighing $87.10 \mathrm{mg}$ consumed $25.84 \mathrm{mg}$ of food as compared to $97.54 \mathrm{mg}$ of food consumed by another prawn weighing $3.29 \mathrm{~g}$ (Table II). Even when the daily food intake was computed against actual body weights of the individuals (i.e. excluding the moult weights) a similar direct relationship between the body size and daily food intake was noticed (Table III). The same trend was also exhibited by the prawns fed in groups (Series 2; Table IV). From the mathematical study of food consumption in various crustaceans as a function of body weight, Sushchenya and Khmeleva (1967) also showed, that under a given set of conditions, the food intake increases with increase in body weight. During the present study, when the daily food intake was expressed as a percentage of body weight the rate of food intake was found to be inversely proportional to body sizes. The value decreased from $38 \%$ for a prawn weighing $80 \mathrm{mg}$ to $3 \%$ for a prawn weighing $5 \mathrm{~g}$ (Table II, see also Table III). The regression equation calculated by the method of Draper and Smith (1966) was as follows.

$\log \left(\right.$ daily food intake $(\mathrm{mg}) \cdot$ body weight $(100 \mathrm{mg})^{-1} \cdot$ day $\left.^{-1}\right)$

$=0.9928-0.6261(\log$ body weight $(\mathrm{mg})-2.679)$ (Fig. 1).

Working on Calanus helgolandicus, Paffenhoffer (1971) also reported that in a log-log system, grazing and ingestion rates per unit body weight decreased almost linearly with increasing body weight.

\section{Growth}

Moulting occurred frequently even when the animals were fed for not 


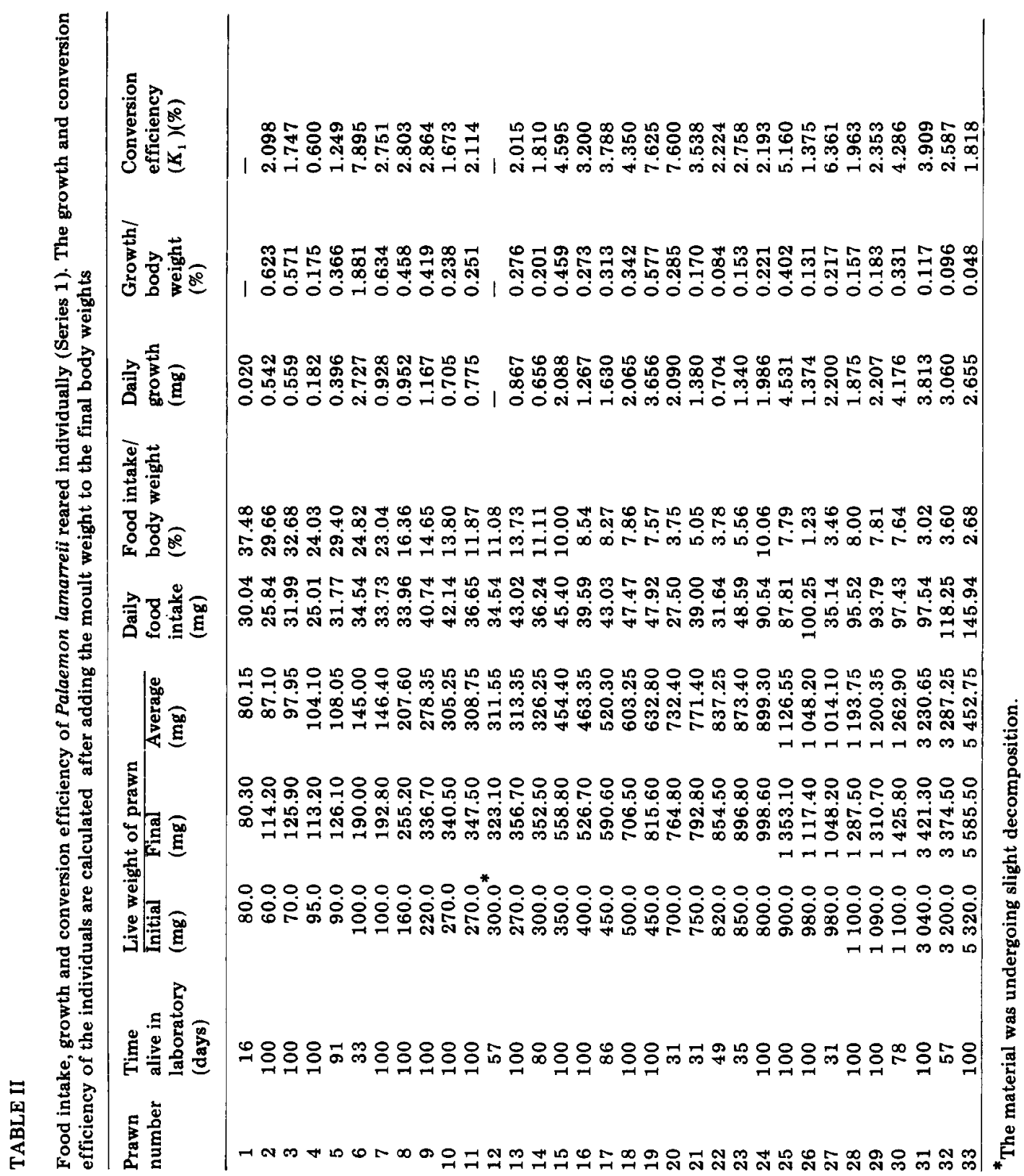


TABLE III

Food intake, growth and conversion efficiency of Palaemon lamarreii reared individually (Series 1). Averages of different weight ranges of individuals that survived for the entire experimental period are given. Growth and conversion efficiency values are calculated using the true final weights of the animals excluding the moults. Numbers indica* ted in parentheses are the number of individuals in the particular weight ranges

\begin{tabular}{|c|c|c|c|c|c|c|c|c|}
\hline $\begin{array}{l}\text { Weight } \\
\text { range } \\
\text { (mg) }\end{array}$ & $\begin{array}{l}\text { Initial } \\
\text { weight } \\
\text { (mg) }\end{array}$ & $\begin{array}{l}\text { Final } \\
\text { weight } \\
\text { (mg) }\end{array}$ & $\begin{array}{l}\text { Average } \\
\text { weight } \\
\text { (mg) }\end{array}$ & $\begin{array}{l}\text { Food } \\
\text { intake/ } \\
\text { day }(\mathbf{m g})\end{array}$ & $\begin{array}{l}\text { Food } \\
\text { intake/ } \\
\text { average } \\
\text { weight } \\
(\%)\end{array}$ & $\begin{array}{l}\text { Growth/ } \\
\text { day } \\
(\mathrm{mg})\end{array}$ & $\begin{array}{l}\text { Growth/ } \\
\text { average } \\
\text { weight } \\
(\%)\end{array}$ & $\begin{array}{l}\text { Conversion } \\
\text { efficiency } \\
\text { (\%) }\end{array}$ \\
\hline $\begin{array}{r}<200 \\
(5)\end{array}$ & $\begin{array}{l}97.00 \pm \\
38.99\end{array}$ & $\begin{array}{c}129.00 \pm \\
53.90\end{array}$ & $\begin{array}{c}113.00 \pm \\
45.19\end{array}$ & $\begin{array}{c}30.11 \pm \\
4.35\end{array}$ & $\begin{array}{c}29.16 \pm \\
8.70\end{array}$ & $\begin{array}{r}0.32 \pm \\
0.26\end{array}$ & $\begin{array}{r}0.27 \pm \\
0.18\end{array}$ & $\begin{array}{c}0.99 \pm \\
0.75\end{array}$ \\
\hline $\begin{array}{c}200-400 \\
(6)\end{array}$ & $\begin{array}{l}296.67 \pm \\
65.58\end{array}$ & $\begin{array}{c}353.33 \pm \\
72.30\end{array}$ & $\begin{array}{l}325.00 \pm \\
72.22\end{array}$ & $\begin{array}{c}41.26 \pm \\
3.01\end{array}$ & $\begin{array}{r}13.22 \pm \\
2.76\end{array}$ & $\begin{array}{c}0.57 \pm \\
0.46\end{array}$ & $\begin{array}{c}0.17 \pm \\
0.11\end{array}$ & $\begin{array}{c}1.34 \pm \\
0.96\end{array}$ \\
\hline $\begin{array}{c}400-800 \\
\text { (3) }\end{array}$ & $\begin{array}{c}583.33 \pm \\
189.29\end{array}$ & $\begin{array}{c}706.67 \pm \\
128.97\end{array}$ & $\begin{array}{l}645.00 \pm \\
158.75\end{array}$ & $\begin{array}{r}61.98 \pm \\
23.71\end{array}$ & $\begin{array}{r}9.41 \pm \\
1.45\end{array}$ & $\begin{array}{c}1.57 \pm \\
0.75\end{array}$ & $\begin{array}{r}0.21 \pm \\
0.13\end{array}$ & $\begin{array}{r}2.42 \pm \\
1.63\end{array}$ \\
\hline $\begin{array}{c}800-1100 \\
(4)\end{array}$ & $\begin{array}{c}1017.50 \pm \\
73.98\end{array}$ & $\begin{array}{c}1077.00 \pm \\
95.13\end{array}$ & $\begin{array}{c}1047.25 \pm \\
67.26\end{array}$ & $\begin{array}{c}94.34 \pm \\
5.06\end{array}$ & $\begin{array}{c}9.05 \pm \\
0.92\end{array}$ & $\begin{array}{r}1.55 \pm \\
0.95\end{array}$ & $\begin{array}{r}0.15 \pm \\
0.09\end{array}$ & $\begin{array}{c}1.74 \pm \\
1.10\end{array}$ \\
\hline
\end{tabular}

\section{TABLE IV}

Food intake, growth and conversion efficiency of Palaemon lamarreii fed in groups (Series 2 ). The values in parentheses indicated in the second and third columns represent the corresponding percentages as in the seventh and ninth columns of Table II

\begin{tabular}{llll}
\hline $\begin{array}{l}\text { Average body weight } \\
\text { and range } \\
(\mathrm{mg})\end{array}$ & $\begin{array}{l}\text { Average daily } \\
\text { food intake } \\
(\mathrm{mg})\end{array}$ & $\begin{array}{l}\text { Average daily } \\
\text { growth } \\
(\mathrm{mg})\end{array}$ & $\begin{array}{l}\text { Average conversion } \\
\text { efficiency }\left(K_{1}\right) \\
(\%)\end{array}$ \\
\hline $\begin{array}{l}115.90 \\
(92.20-136.40)\end{array}$ & $\begin{array}{c}18.72 \\
(16.13)\end{array}$ & $\begin{array}{l}0.50 \\
(0.43)\end{array}$ & 2.60 \\
$\begin{array}{c}150.30 \\
(121.20-183.00)\end{array}$ & $\begin{array}{c}26.20 \\
(17.43)\end{array}$ & $\begin{array}{c}1.44 \\
(0.96)\end{array}$ & 5.30 \\
$\begin{array}{c}506.90 \\
(344.70-586.20)\end{array}$ & $\begin{array}{c}27.20 \\
(5.37)\end{array}$ & $\begin{array}{c}0.97 \\
(0.18)\end{array}$ & 3.50 \\
$\begin{array}{c}976.50 \\
(865.00-1130.00)\end{array}$ & $\begin{array}{c}87.20 \\
(8.93)\end{array}$ & $\begin{array}{c}1.29 \\
(0.13)\end{array}$ & 1.30 \\
\hline
\end{tabular}

longer than $4 \mathrm{~h} /$ day. At the end of the experimental period, total growth was determined by adding the total wet weights of all the exuviae produced by each prawn to the total increase in wet weight of that individual. The recorded values of per day growth were very low, ranging from 0.02 to $4.50 \mathrm{mg}$ wet body weight (Tables II and III). The percentage rate of growth in relation to body weight showed a linear inverse relationship in a $\log -\log$ system.

Log (growth (mg) $\cdot$ body weight $(100 \mathrm{mg})^{-1} \cdot$ day $\left.^{-1}\right)$

$=1.4202-0.4766(\log$ body weight $(\mathrm{mg})-2.7235),($ Fig. 2$)$. 


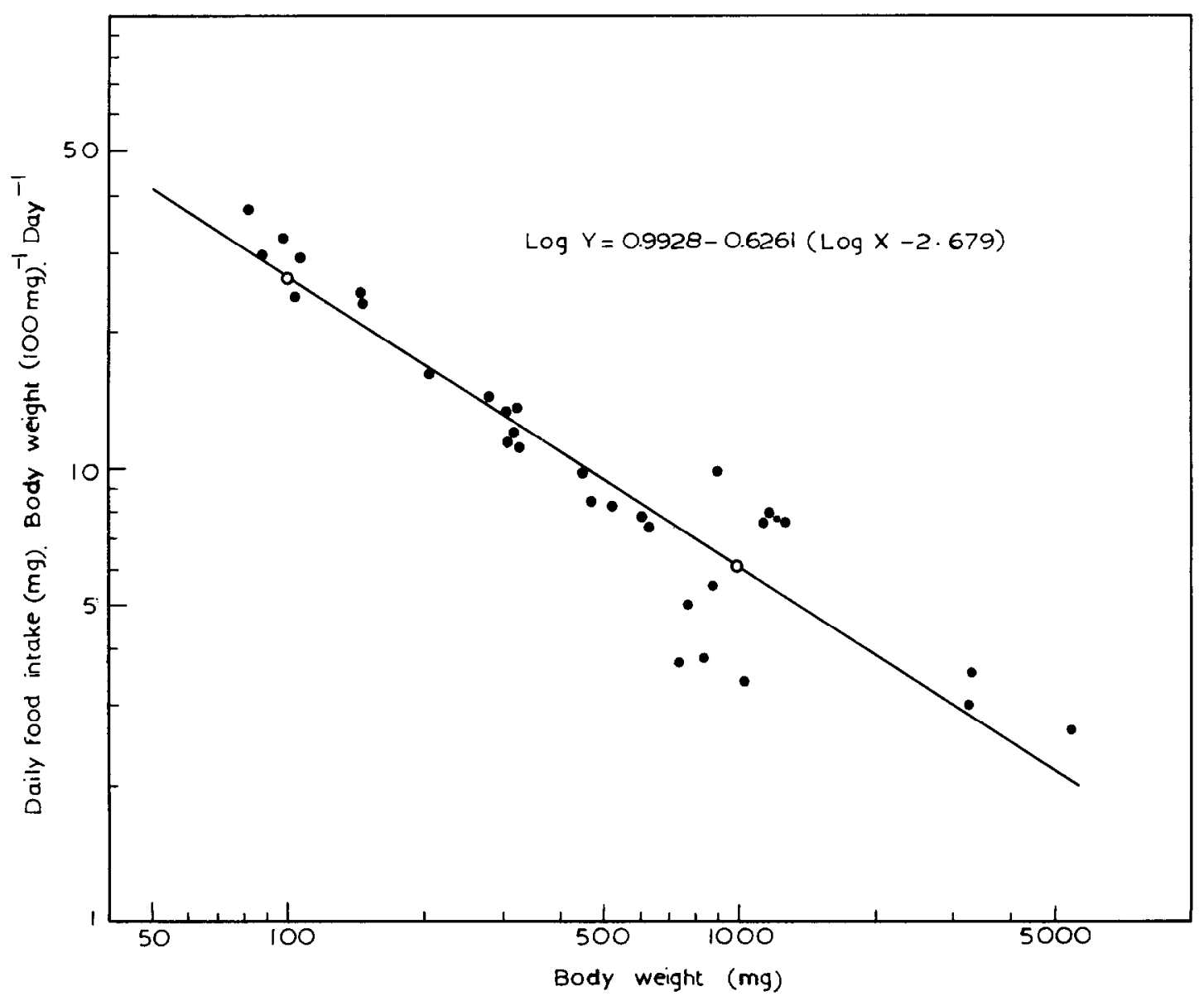

Fig. 1. Regression line indicating the relationship between the body weight of Palaemon lamarreii and daily food intake.

The growth rate decreased from $0.62 \%$ for an individual weighing $87.10 \mathrm{mg}$ to $0.12 \%$ for an individual weighing $3.29 \mathrm{~g}$. In Macrobrachium brevicornis, Rajyalakshmi (1961) reported that the specific growth rate was highest in the young and decreased with age (size). Growth was observed to bear an inverse exponential relationship to size in $M$. rosenbergii (Rajyalakshmi, 1964; Bhimachar, 1965). George (1959) also observed that in Metapenaeus monoceros growth rate decreased in larger specimens. To compare the present values of growth rates with those obtained for Palaemon lamarreii by Sitaramiah (1966), relative growth rates in percentages per day were also calculated using the method detailed in Fisher (1950) (Table V A). These values ranged from 0.048 to $1.95 \%$. The average values for different weight ranges of prawns were calculated and are represented in Table V B. On the whole, the values are comparatively low but indicate that the daily relative 


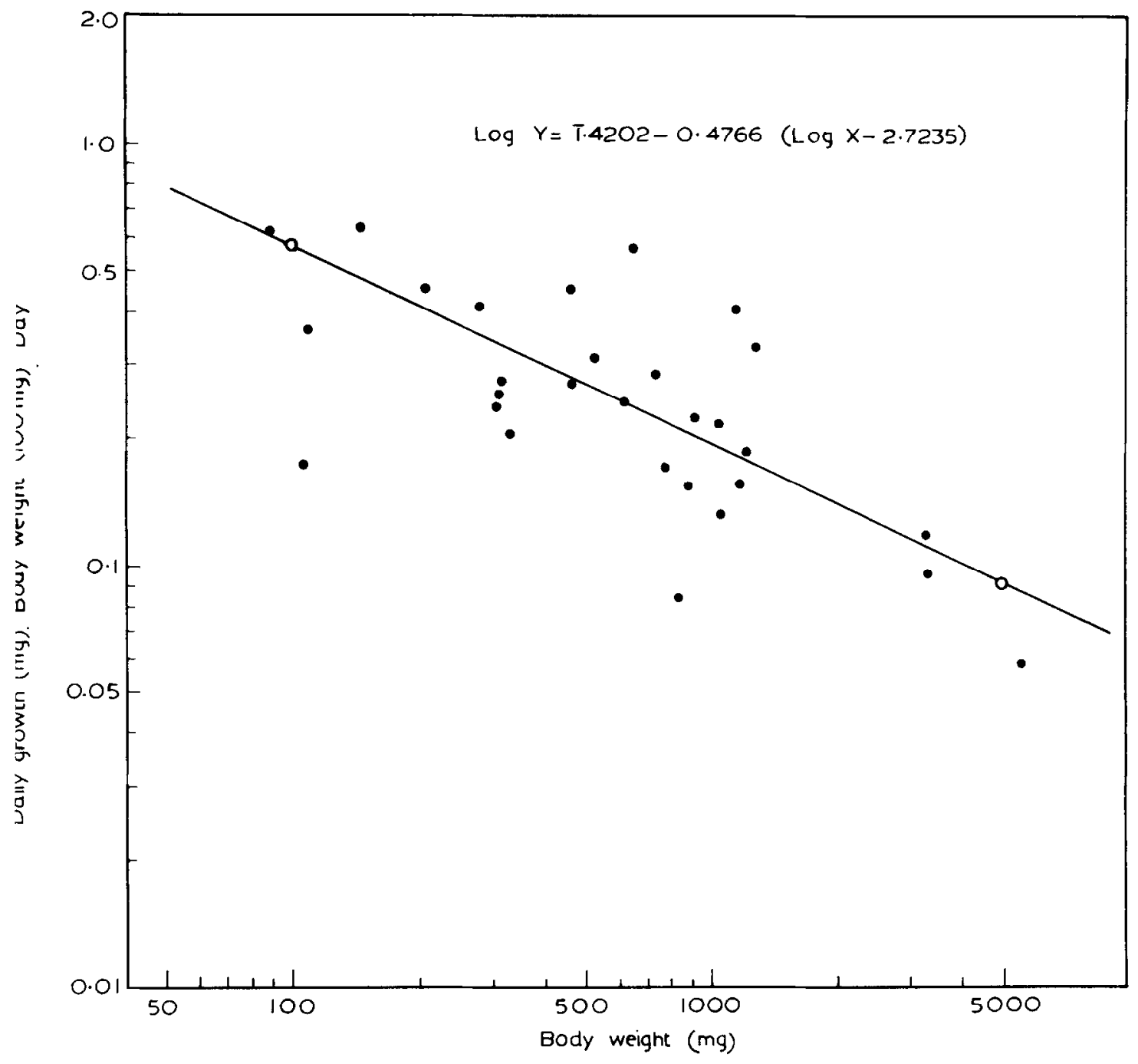

Fig. 2. Regression line indicating the relationship between the body weight of Palaemon lamarreii and daily growth.

growth rate also bears in an inverse relationship to body weight.

The same species of prawn fed ad libitum for 85 days, with an initial weight per individual of $0.0366 \mathrm{~g}$ and absolute growth rate of $0.0007 \mathrm{~g}$, a calculation, as below, shows a relative growth rate of $1.1357 \%$ per day as compared to the tabulated value of $2.69 \%$ (see Sitaramiah, 1966). If $m i=$ initial weight, 
TABLE V A

Relative growth rates of Palaemon lamarreii reared individually (Series 1)

\begin{tabular}{|c|c|c|c|c|c|}
\hline $\begin{array}{l}\text { Prawn } \\
\text { number }\end{array}$ & $\begin{array}{l}\text { Time } \\
\text { alive in } \\
\text { laboratory } \\
\text { (days) }\end{array}$ & $\frac{\text { Live weight }}{\text { Initial }(m i)}$ & $\begin{array}{l}\frac{\text { of prawn }}{\text { Final }(m f)} \\
(\mathrm{mg})\end{array}$ & $m f / m i$ & $\begin{array}{l}\text { Relative growth } \\
\text { rate (\%/day) }\end{array}$ \\
\hline 2 & 100 & 60.0 & 114.2 & 1.908 & 0.646 \\
\hline 3 & 100 & 70.0 & 125.9 & 1.748 & 0.587 \\
\hline 4 & 100 & 95.0 & 113.2 & 1.192 & 0.175 \\
\hline 5 & 91 & 90.0 & 126.1 & 1.403 & 0.372 \\
\hline 6 & 33 & 100.0 & 190.0 & 1.900 & 1.950 \\
\hline 7 & 100 & 190.0 & 192.8 & 1.928 & 0.656 \\
\hline 8 & 100 & 160.0 & 255.2 & 1.592 & 0.465 \\
\hline 9 & 100 & 220.0 & 336.7 & 1.531 & 0.427 \\
\hline 10 & 100 & 270.0 & 340.5 & 1.261 & 0.232 \\
\hline 11 & 100 & 270.0 & 347.5 & 1.285 & 0.258 \\
\hline 13 & 100 & 270.0 & 356.7 & 1.321 & 0.279 \\
\hline 14 & 80 & 300.0 & 352.5 & 1.175 & 0.202 \\
\hline 15 & 100 & 350.0 & 558.8 & 1.592 & 0.465 \\
\hline 16 & 100 & 400.0 & 526.7 & 1.317 & 0.276 \\
\hline 17 & 86 & 450.0 & 590.6 & 1.311 & 0.315 \\
\hline 18 & 100 & 500.0 & 706.5 & 1.413 & 0.346 \\
\hline 19 & 100 & 450.0 & 815.6 & 1.812 & 0.596 \\
\hline 20 & 31 & 700.0 & 764.8 & 1.093 & 0.298 \\
\hline 21 & 31 & 750.0 & 792.8 & 1.058 & 0.182 \\
\hline 23 & 35 & 850.0 & 896.8 & 1.055 & 0.153 \\
\hline 24 & 100 & 800.0 & 998.6 & 1.248 & 0.222 \\
\hline 25 & 100 & 900.0 & 1353.1 & 1.503 & 0.408 \\
\hline 26 & 100 & 980.0 & 1117.4 & 1.140 & 0.137 \\
\hline 27 & 31 & 980.0 & 1048.2 & 1.069 & 0.216 \\
\hline 28 & 100 & 1100.0 & 1287.5 & 1.170 & 0.157 \\
\hline 29 & 100 & 1090.0 & 1310.7 & 1.204 & 0.186 \\
\hline 30 & 78 & 1100.0 & 1425.8 & 1.287 & 0.324 \\
\hline 31 & 100 & 3040.0 & 3421.0 & 1.127 & 0.120 \\
\hline 32 & 57 & 3200.0 & 3374.5 & 1.058 & 0.099 \\
\hline 33 & 100 & 5320.0 & 5585.5 & 1.049 & 0.048 \\
\hline
\end{tabular}

\section{TABLE V B}

Effect of body size on the relative growth rate of Palaemon lamarreii reared individually (Series 1 )

\begin{tabular}{lccl}
\hline Prawn numbers & $\begin{array}{l}\text { Weight range } \\
(\mathbf{m g})\end{array}$ & $\begin{array}{l}\text { Total number } \\
\text { of animals }\end{array}$ & $\begin{array}{l}\text { Relative growth rate } \\
(\% / \text { day })\end{array}$ \\
\hline $2-7$ & $50-150$ & 6 & $0.490 \pm 0.210$ \\
$8-11,13-15$ & $150-350$ & 7 & $0.334 \pm 0.111$ \\
$16-25$ & $400-900$ & 10 & $0.312 \pm 0.135$ \\
$26-30$ & $950-1100$ & 5 & $0.206 \pm 0.023$ \\
$31-33$ & $3000-5300$ & 3 & $0.089 \pm 0.052$ \\
\hline
\end{tabular}


$\ln (m i+$ number of days $X$ absolute growth rate per day $)-m i$

number of days

$=\frac{\ln (0.0366+85 \times 0.0007)-\ln 0.0366}{85} \times 100=1.1357$.

The low values obtained in the present experiment (averaging 0.363 ) in comparison to the recalculated value of $1.136 \%$ of Sitaramiah (1966) may be due to the controlled feeding schedule adopted during the present study, in contrast to the ab libitum feeding adopted by Sitaramiah (1966). The low growth rate may also be due to high temperature, characteristic specific growth rate cycle and/or confinement to the aquaria, as suggested by other workers (Pearson, 1939; Hudinaga, 1942; Marshall, 1945; Lunz, 1958; Costello and Allan, 1959; Eldred et al., 1961).

\section{Conversion efficiency}

The efficiency with which Palaemon lamarreii converted food material into body substance, ranged from 1 to $8 \%$ when fed individually (Tables II and III). The values did not show any appreciable change when the animals were fed in groups (Table IV). When represented in a log-log system, the values of conversion efficiency of the prawns in Series 1 bore a complex relationship to the body weight of the animals.

Log conversion efficiency $(\%)=0.4538+0.5805(\log$ body weight $(\mathrm{mg})-$ 2.4602) (Fig. 3 A).

Beyond the maximum level, the regression analysis showed a slight decline in conversion efficiency, in relation to the body weight.

Log conversion efficiency $(\%)=0.5809-0.285$ (log body weight $(\mathrm{mg})$ 3.0788) (Fig. 3 B).

However, this decline is not statistically significantly different from zero. The values of conversion efficiency indicate that $P$. lamarreii of the size range of $600-800 \mathrm{mg}$ converted food most efficiently. On the whole, the present values of conversion efficiency seem to be rather low, but are comparable to gross efficiency values obtained for adult Daphnia pulex (range: 0.43$1.25 \%)$ reported by Richman (1958).

McLeese (1972 $\mathrm{a}$ and $\mathrm{b}$ ) has stressed the importance of rearing decapods under laboratory conditions to ensure better growth of these animals. But he reported heavy mortality of the lobster Homarus americanus in captivity, although the food offered was sufficient, and attributed this mortality to the phenomena of both moulting and non-moulting. During the present study, however, a survival rate of $61 \%$ was obtained for Palaemon lamarreii even when the prawns were fed for only $4 \mathrm{~h}$ a day. It is likely that, if food is offered ad libitum, the survival rate would be even higher. The cannibalistic 


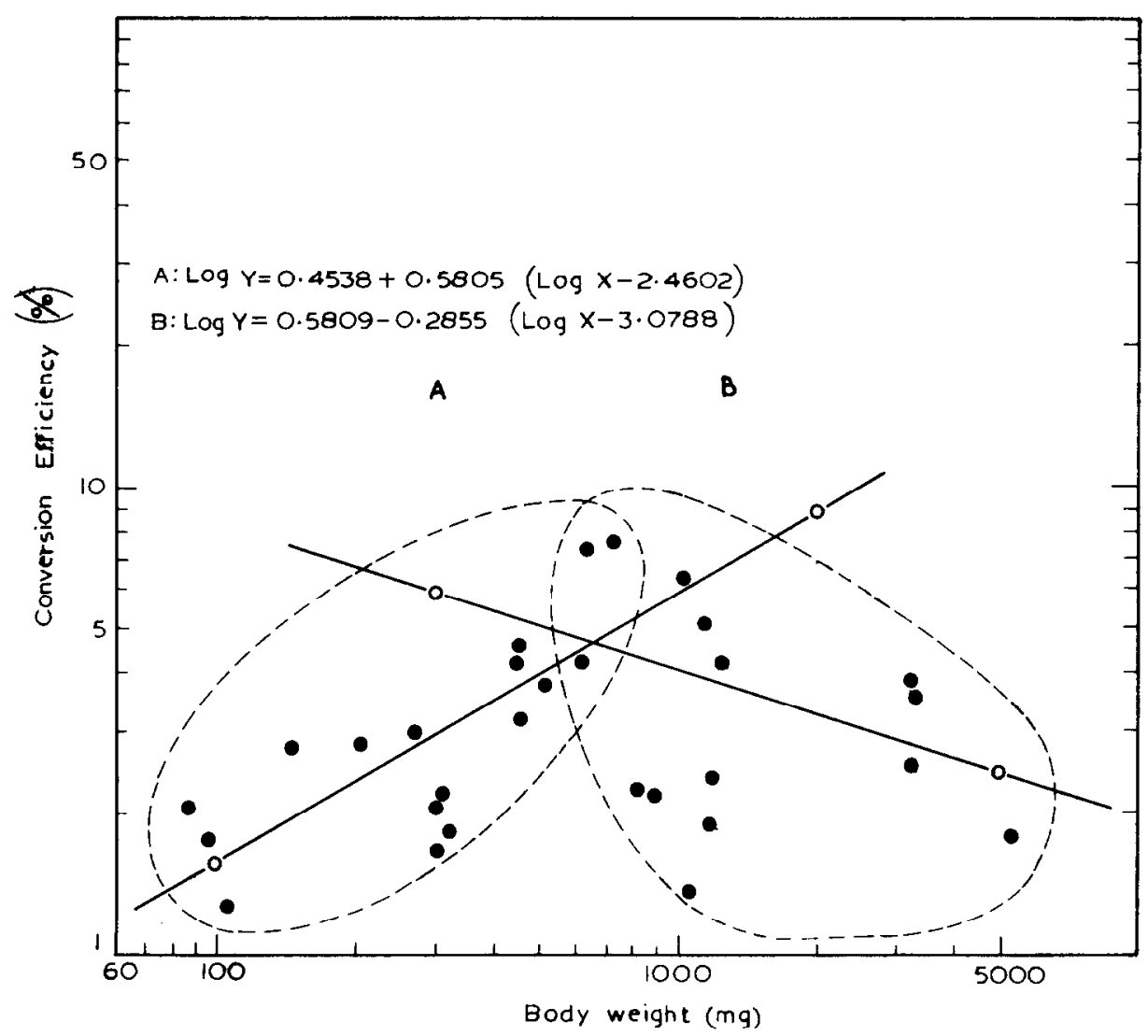

Fig. 3. Regression lines indicating the relationship between the body weight of Palaemon lamarreii and conversion efficiency $\left(K_{1}=\right.$ increase in body weight $(\mathrm{mg}) \times 100 /$ food intake $(\mathbf{m g}))$.

behaviour observed among $P$. lamarreii reared in groups may also be due to the restricted feeding schedule adopted during the present experiment. Perhaps, on ad libitum diet, this mortality due to cannibalism can be overcome. It is suggested that these prawns can be successfully maintained and grown in captivity.

The dependence of metabolism on the body size has long been recognized as a variable of importance when comparing physiological activities of animals (Von Bertalanffy, 1951). Palaemon lamarreii in the size range 600-800 mg exhibited the best conversion efficiency and hence this would be the ideal size range for conducting feeding experiments.

The moulting process in crustaceans has been correlated with changes in their metabolism, rate of tissue growth and behaviour (Bittner and Kopanda, 1973). Since Palaemon lamarreii exhibited moulting at regular intervals, the moults themselves can probably be used to estimate the biomass of these prawns (see also Lasker, 1966). During the present study, the prawns fed $4 \mathrm{~h}$ 
a day exhibited a low relative growth rate of $0.363 \%$, underwent moulting once in $18 \pm 5$ days and each cast moult averaged $14 \%$ of the animal's dry weight. Since moulting is correlated with growth, it is conceivable that $P$. $\mid \boldsymbol{a}$ marreii fed food ad libitum and exhibiting a relative growth rate of $1.357 \%$ (Sitaramiah, 1966), would moult more frequently. Very frequent moulting would thus be adding a sizable quantity of organic matter to the detritus of a freshwater habitat. The quantity of organic matter added to the detritus deposit would, however, depend on the density of population of the prawns and the nutrient condition of the habitat. The importance of such organic detritus deposits in the sea has been discussed by Parsons and Strickland (1962). Dense deposits of these prawn moults would render the freshwater bottom sediments rich in chitin and protein and Sai Sastry (1973) has reported that such bottom material, rich in chitin and protein can be used as a good source of raw material for preparing various animal feeds.

Further work on the feeding regime is in progress, to determine the ideal density and feeding schedule that should be adopted to ensure best survival and growth of Palaemon lamarreii in captivity and to promote the value of these freshwater prawns commercially.

\section{REFERENCES}

Bhimachar, B.S., 1965. Life history and behaviour of Indian prawns. Fish. Technol., 2 (1): 1-11.

Bittner, G.D. and Kopanda, R., 1973. Factors influencing moulting in the crayfish Procambarus clarki. J. Exp. Zool., 186 (1): 7-16.

Chopra, B. and Tiwari, K.K., 1947. Decapod crustacea of the Patna State, Orissa. Rec. Indian Mus., 213-214.

Cole, H.A. and Waugh, G.D., 1959. The problem of stunted growth in oysters. J. Cons., 24: $355^{-3}-365$.

Comita, G.W., 1964. The energy budget of Diaptomus siciloides, Lilljeborg. Verh. Int. Ver. Limnol., XV: 646-653.

Costello, T.J. and Allan, D.M., 1959. Migration and growth of the pink shrimp. Annual Report, Fish. Res. Galveston Biol. Lab., U.S. Fish and Wildl. Serv. Cir. No. 62, pp. 13-18.

Delmando, M.N. and Rabanol, H.R., 1956. Rate of Growth of the Sugpo (Jumbo Tiger Shrimp) Penaeus monodon (Fabricus), with Notes on it's Culture in Brackish Water Ponds. Indo-Pac. Fish. Counc., 6th Sess., 5, 12 pp.

De Man, J.G., 1908. Decapod crustacea with an account of a small collection from brackish water near Calcutta and in the Dacca District. In: The Fauna of Brackish Water Ponds at Port Canning, Lower Bengal, Rec. Indian Mus., 11: 211-231.

Draper N. and Smith, H., 1966. Applied Regression Analysis. John Wiley, New York, N. Y., $407 \mathrm{pp}$.

Eldred, B., Ingle, R.M., Woodburn, K.D., Hutton, R.F. and Jones, H., 1961. Biological Observations on the Commercial Shrimp Penaeus durarum Burkenroad, in Florida Waters. Professional Papers J.C. Series 3. Florida State Board of Conservation Marine Laboratory, St. Petersburg, Fla.

Fisher, R.A., 1950. Statistical Methods of Research Workers. Oliver and Boyd, London, $338 \mathrm{pp}$. 
Forster, J.R.M., 1972. Some methods of binding prawn diets and their effects on growth and assimilation. J. Cons. Int. Explor. Mer., 34 (2): 200-216.

George, M.J., 1959. Notes on the bionomics of the prawn Metapenaeus monodon Fabricus. Indian J. Fish., 5 (2): 268-279.

Hudinaga, M., 1942. Reproduction, development and rearing of Penaeus japonicus Bate. Jpn. J. Zool., 10: 305-392.

Jerde, C.W. and Lasker, R., 1966. Moulting of Euphasid shrimps. Shipboard observations. Limnol. Oceanogr., 11: 120-124.

Kemp, S., 1915. Fauna of Chilka lake: Crustacea, Decapoda. Mem. Indian Mus., 5: 199325.

Khmeleva, N.N., 1967. Transformatsiya energii in Artemia salina (L). (Energy transformation in A. salina (L).) Dokl. Akad. Nauk. SSSR, 175 (4): 934-937.

Kryutchkova, N.M., Sládeček, V., 1969. Quantitative relations of the feeding and growth of Daphnia pulex obtusa (Kurz) Scourfield. Hydrobiologia, 33: 47-64.

Lasker, R., 1964. Moulting frequency of a deep sea crustacean, Euphausia pacifica. Nature (London), 203 (4940): 96.

Lasker, R., 1966. Feeding, growth, respiration, carbon utilization of a Euphausid crustacean. J. Fish. Res. Board Can., 23 (9): 000-000.

Ling, S.W., 1962. Studies on rearing of larvae and juveniles and culturing of adults of Macrobrachium rosenbergii (De Man). Curr. Aff. Bull. Indo-Pac. Fish. Counc., 35: 111.

Lunz, G.R., 1958. Pond cultivation of shrimp in South Carolina. Proc. Gulf Caribb. Fish. Inst., 10th Annu. Sess., No. 1957, pp. 44-48.

McLeese, D.W., 1972 a. Initial Experiments on Growth of the American Lobster (Homarus americanus) in Captivity. Fish. Res. Board Can., Tech. Rep. No. 320, 22 pp.

McLeese, D.W., 1972 b. Effects of several factors on the growth of the American lobster (Homarus americanus) in captivity. J. Fish. Res. Board Can., 29 (12): 1725-1730.

Marshall, N., 1945. The moulting without growth of spiny lobsters, Panulirus argus kept in a live car. Trans. Am. Fish. Soc., 75: 267-269.

Marshall, S.M. and Orr, A.P., 1960. Feeding and nutrition. In: T.H. Waterman (Editor), The Physiology of Crustacea. Academic Press, New York, N.Y., pp. 227-255.

Mason, D.T., 1963. The growth response of Artemia salina (L.) to various feeding regimes. Crustaceana (Leiden), 5: 138-150.

Monokov, A.V., 1972. Review of studies on feeding of aquatic invertebrates conducted at the Institute of Biology of Inland waters, Academy of Sciences, USSR. J. Fish. Res. Board Can., 29: 363-383.

Needham, A.E., 1946. Ecdysis and growth in crustacea. Nature (London), 158: 667-668.

New, M.B., 1976. A review of dietary studies with shrimp and prawns. Aquaculture, 9: 101-144.

Paffenhöffer, G.A., 1971. Grazing and injection rates of nauplii and adults of the marine planktonic copepod Calanus helgolandicus. Mar. Biol., 11 (3): 286-298.

Panikkar, N.K. and Aiyer, R.G., 1939. Observations on breeding in brackish water animals of Madras. Proc. Indian Acad. Sci., 9: 343-383.

Parsons, T.R. and Strickland, J.D.H., 1962. Oceanic detritus. Science, 136: 313-314.

Patwardhan, S.S., 1937. Palaemon. Indian Zool. Mem., 6: 1-120.

Pearson, J.C., 1939. The early life histories of some American Penaedae, chiefly the commercial shrimp Penaeus setiferus (Linn.). Bull. U.S. Bur. Fish., XLIX: 1-13.

Prawn Fisheries of India., 1969. Bull. Cent. Mar. Fish. Res. Inst., ICAR. No. 14, 303 pp.

Rajyalakshmi, T., 1961. Observations on the biology and fishery of Metapenaeus brevicornus (M. Edw.) in the Hoogly estuarine system. Indian J. Fish., 8 (2): 383-403.

Rajyalakshmi, T., 1964. On the age and growth of some estuarine prawns. Proc. Indo-Pac. Fish. Counc, $11: 52-64$.

Raman, K., 1967. Observations on the fishery and biology of the giant freshwater prawn Macrobrachium rosenbergii (De Man). Proc. Symp. Crustacea., Mar. Biol. Assoc. India., Part II, pp. 649-669. 
Rao, R.M., 1967. Studies on the biology of Macrobrachium rosenbergii (De Man) of the Hoogly estuary with notes on its fishery. Proc. Natl. Inst. Sci. India, 33 (5-6): 252279.

Reeve, M.R., 1963. Growth efficiency in Artemia under laboratory conditions. Biol. Bull., 125(1): 133--145.

Regnault, M., Campillo, A. and Luquet, P., 1974. Croissance des crevettes Crangon crangon et Palaemon serratus soumises a un régime artificiel: influence du mode de présentation et du mode de se'chage d'aliment. Cah. Biol. Mar., XVI: 1-20.

Richman, S., 1958. Transformation of energy in Daphnia pulex. Ecol. Monogr., 28: 273291.

Richman, S., 1964. Energy transformation studies on Diaptomus oregonensis. Verh. Ver. Limnol., XV: $654-659$.

Sai Sastry, A.G.R., 1973. Fishing for prawns. Sci. Rep., 1973: 118-122.

Sitaramiah, P., 1966. Studies on growth rates of some freshwater animals. J. Anim. Morphol. Physiol., 13: 103-113.

Sushtchenya, L.M., 1962. Quantitative data on nutrition and energy balance of Artemia salina (L.). Dokl. Akad. Nauk, SSSR, Ser. Biol., 143(5): 1205-1207.

Sushtchenya, L.M. and Khmeleva, N.N., 1967. Food consumption as a function of body weight in crustaceans. Dokl. Akad. Nauk. SSSR, 176 (6): 1428-1431.

Von Bertalanffy, L., 1951. Metabolic types and growth types. Am. Nat., 821: 111-117. 